\title{
Can involvement increase trust in a confusing online setting? Implications for marketing strategy
}

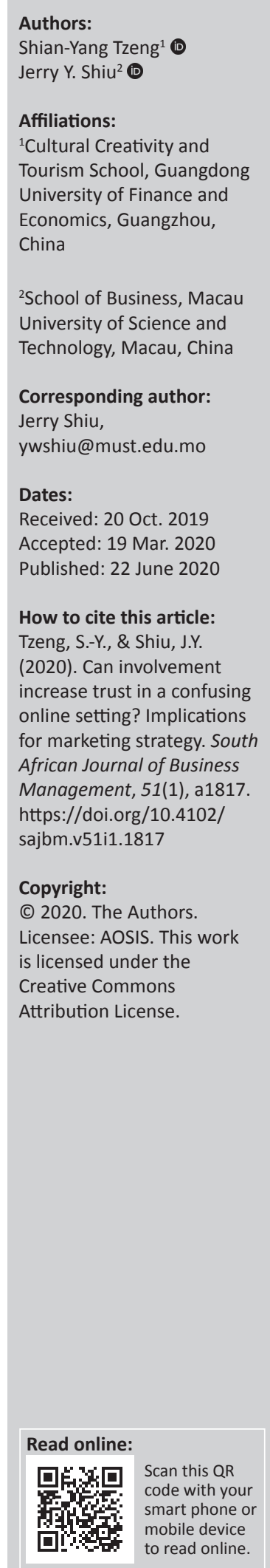

Purpose: Customer trust toward e-commerce has been unsettled by recent unethical events. Involvement, the level of personal relevance of an object or event, has been proved to enhance trust. Nevertheless, in a complicated online shopping environment, the relationship between involvement and trust might undergo changes. Therefore, this study aims to investigate how consumer involvement can be translated into trust that is crucial to the success of online transactions in such a confusing setting.

Design/methodology/approach: This study explores the relationships between involvement (i.e., purchase and product involvement) and trust (i.e., trust in e-vendors, retail websites and brands). This study also tests the moderating effects of confusion on the purchase involvementtrust relationship. Using 570 effective samples randomly collected in Guangdong, China, this study employed structural equation modelling to test a proposed hypotheses.

Findings: The results show that purchase involvement has a negative impact on trust in e-vendors, retail websites and brands, whereas product involvement demonstrates a positive effect. Moreover, confusion reinforces the negative relationship between purchase involvement and trust in e-vendors.

Practical implications: To increase customer trust, marketers should invite regular customers to recommend their products and services, become associated with e-service providers and brands and design distinct logos, slogans and advertising styles.

Originality/value: This paper explores the direct effect of involvement on trust in multiple online contextual situations (e.g., platforms, brands and e-vendors), as well as the moderating effect of confusion on the involvement-trust relationship.

Keywords: online transactions; confusion; involvement; trust; China.

\section{Introduction}

Because of the characteristics of Internet transactions, consumer trust is the foundation of e-commerce (Kim, Ferrin, \& Rao, 2008). However, the emergence of negative news, such as Facebook's privacy breach (Vogelstein, 2018), has perturbed consumer-supplier trust. For example, according to a recent survey of 25 countries (CIGI-Ipsos, 2018), 57\% of the respondents expressed their increasing concerns about online privacy and $12 \%$ of the participants claimed that they would make fewer online purchases in the future. Moreover, in China, $21.5 \%$ of cross-border e-commerce users have confronted quality problems; and $39.4 \%$ of interviewed shoppers reported that they will switch to other platforms after learning about the quality problems of online commodities (iiMedia Report, 2018). The aforementioned situations might decrease customer trust toward web-based retailing. Therefore, determining how to regain customer trust in online transactions is essential for both practitioners and scholars.

Involvement has been proven to enhance trust beliefs (Chen, Wu, \& Chien, 2016; Sanchez-Franco, 2009). Customers with a high level of knowledge about a service tend to make better purchase decisions than those with a low level of knowledge (Yang, Hung, Kai, \& Farn, 2006). When consumers invest long-term, considerable effort in searching for and processing information or expressing ongoing concerns about products or services, the perceived risks associated with the products or services can be reduced (Bloch \& Richins, 1983). Therefore, enduring involvement (i.e., product involvement) can enable customers to effectively assess retailers' capabilities and benevolence, which in turn helps to build customers' trust (Chen et al., 2016; Sanchez-Franco, 2009). By contrast, other consumers spend time and effort seeking or processing information to evaluate alternatives only during the purchase process because of the high perceived risks. This type of situational involvement (i.e., purchase involvement) is temporarily established, which can 
also increase their trust toward retailing (Sanchez-Franco, 2009). Although several scholars have argued that trust considerably influences consumer involvement in trusted partners, such as financial companies (Chen et al., 2016; Hansen, 2017) and trading partners (Li, Li, \& Feng, 2015), the reverse direction (i.e., the effect of involvement on trust) deserves more attention to a lack of initial trust.

However, determining whether involvement can be successfully translated into online trust remains a challenge. Over the past few years, many global brands on e-commerce platforms have grown at a relatively rapid rate (Ecommerce Foundation, 2017). Through their rapid expansion efforts, many brands or e-retailers have adopted remarkably similar logos, product designs and displays, and marketing tactics, particularly in China (Bao, 2013). In such a confusing online shopping environment, consumers with limited product knowledge can easily become overwhelmed and struggle when making purchase decisions (Shiu \& Tzeng, 2018; Walsh, Hennig-Thurau, \& Mitchell, 2007). Massive amounts of unfamiliar and uncertain information raise the threshold of involvement that consumers must cross if they are to trust an e-seller (Kim et al., 2008). The continued increase of uncertainty in e-markets necessitates further examination of two questions: whether both types of involvement still positively influence trust; and whether consumer confusion affects the involvement-trust relationship.

To fully consider the online shopping environment, this paper contributes by exploring the direct effect of purchase involvement and product involvement on trust in all online contextual situations (e.g., platforms, brands and e-venders) and the moderating effect of confusion on the involvementtrust relationship.

\section{Theory development and research hypotheses \\ Consumer involvement}

The customers' degree of involvement affects their purchase decisions (Laurent \& Kapferer, 1985; Pieniak, Verbeke, Scholderer, Brunsø, \& Olsen, 2008). To further understand the behaviour of consumers when making decisions, scholars have studied their involvement in various industries, such as banking (Sanchez-Franco, 2009), food (Pieniak et al., 2008), wine (Rahman \& Reynolds, 2015) and tourism (Ferns \& Walls, 2012). From the perspectives of different industries, these studies draw a full-scale map of the relationships between involvement and several factors, such as satisfaction, trust, commitment and positive mood. Their findings offer managerial implications for marketers who attempt to incorporate involvement into their marketing strategies.

Involvement, which exhibits relevance to personal values (Barki \& Hartwick, 1994; Bloch \& Richins, 1983), is an individual, internal interest of intensity, direction and persistence toward specific products (Andrews, Durvasula, \& Akhter, 1990). Although many papers have classified involvement into various types, product and purchase involvement have been widely acknowledged as its two main categories (Belanche, Flavián, \& Pérez-Rueda, 2017; Bloch \& Richins, 1983; Lockshin, Spawton, \& Macintosh, 1997; Vanwesenbeeck, Walrave, \& Ponnet, 2016). Product involvement (or enduring involvement) is a feeling of interest, enthusiasm and excitement about specific product categories that consumers build over the long term (Houston \& Rothschild, 1978), while purchase involvement (or situational involvement) is stimulated by a particular situation, such as a purchase occasion, and prompts prepurchase internal or external information searches to reduce the perceived risks associated with the selection of products or services (Bloch \& Richins, 1983; Houston \& Rothschild, 1978).

\section{Trust in online shopping}

Consumer trust in products or service providers is a major factor that fuels the rapid development of e-commerce (Gefen, 2000). Given their inability to confirm the quality of a product in person, consumers have to trust the entire e-commerce mechanism to determine the transactions that follow (Lee \& Turban, 2001). Customer trust is a psychological state that allows consumers to accept their own vulnerability and take risks based on their positive expectations regarding the intentions and behaviours of the other party (Singh \& Sirdeshmukh, 2000). Grabner-Kräuter and Kaluscha (2003) performed an integrative review of 11 empirical studies on trust in e-commerce and found that most of these studies have explored the consumers' trust in online retailers or retail websites. Online retailers are stores which sell products or services via the Internet, while retail websites are online portals that allow online businesses to manage their website, marketing, sales and operations. Many authors highlighted brand trust as another important research object that can help customers reduce their uncertainty and simplify their choices of online shopping (Plassmann, Kenning, Deppe, Kugel, \& Schwindt, 2008). Even though many e-merchants are unknown to consumers, they still engage in business online because e-service providers play an intermediary role in guaranteeing customers' equity. Moreover, brands, public images conceived of as something to be marketed, can shape some consumers' perceptions toward products. When product information is accessed from unfamiliar retailers, the brand name can increase the customer's confidence in claims (Delgado-Ballester \& Munuera-Alemán, 2001). Trust in online shopping must be conceptualised as a separate construct that functions differently in the e-commerce mechanism with an aim to reduce uncertainty.

The inherent nature of perceived risks somehow bridges the relationship between involvement and trust in the e-commerce context. Sanchez-Franco (2009) investigated the moderating effect of involvement on the relationship between trust and commitment and argued that when product involvement exists, the importance of trust is reduced. By contrast, high purchase involvement results from a high perceived risk, thereby enhancing the relevance of trust. People tend to make trust-related assumptions about 
others based on what they know (Riquelme, Román, Cuestas, \& Iacobucci, 2019), but in an uncertain situation, people confirm their beliefs through experiential evidence (Ouyang, Gursoy, \& Chen, 2019), such as their perceptions toward a website. After identifying their needs, those customers with a high purchase involvement engage in an information search to avoid uncertainty. They feel vulnerable in the unfamiliar online world because of their lack of confidence in their ability to purchase their desired product online (Sanchez-Franco, 2009). Therefore, those purchase-involved consumers who temporarily increase the relevance or their interest toward a product or service tend to seek information from formal or informal sources to evaluate their alternatives and ponder over their purchase decisions. These temporal risk-reduction activities may reinforce the customers' trust in any trading party in e-commerce (Sanchez-Franco, 2009). As their degree of purchase involvement increases, these customers' level of trust in e-retailers, brands being sold online and e-service providers increases. The following hypotheses are proposed:

H1a: A consumer's purchase involvement is positively related to his or her trust in e-retailers.

H1b: A consumer's purchase involvement is positively related to his or her trust in brands being sold online.

H1c: A consumer's purchase involvement is positively related to his or her trust in e-service providers.

On the other hand, familiarity with products can make consumers feel secure when shopping online because they know how to identify useful information and where to find bargains (Kim et al., 2008). Product involvement allows customers to develop expectations regarding the trading parties (Sanchez-Franco, 2009). Therefore, given their rich experience or knowledge about e-commerce, those consumers with a high product involvement build their faith in others' benevolence, competence and integrity, which consequently develops their trust in online businesses (McKnight, Choudhury, \& Kacmar, 2002). The following hypotheses are proposed:

H2a: A consumer's product involvement is positively related to his or her trust in e-retailers.

H2b: A consumer's product involvement is positively related to his or her trust in brands being sold online.

H2c: A consumer's product involvement is positively related to his or her trust in e-service providers.

\section{Online consumer confusion}

Consumer confusion is a mental state with conscious and unconscious elements in which a customer struggles when making purchase decisions (Moon, Costello, \& Koo, 2016). Consumer confusion can occur before or after the purchase (Mitchell, Walsh, \& Yami, 2005) and can be viewed as the failure to develop an accurate interpretation of the various facets of a product or service during the information processing procedure (Turnbull, Leek, \& Ying, 2000). Three types of confusion, namely, similarity, overload and ambiguity have been identified from the literature (Turnbull et al., 2000; Walsh et al., 2007). Similarity, confusion refers to the consumers' propensity to think that different products in a product category are similar with the brand names, attributes or quality (Walsh et al., 2007). Overload confusion takes place when individuals are bombarded with an abundance of information (Mitchell et al., 2005). Ambiguity confusion occurs when individuals are forced to re-evaluate and revise current beliefs or assumptions about the product or purchasing environment (Mitchell et al., 2005). These three types of confusion not only take place when shopping in physical stores but also when shopping online (Mitchell et al., 2005). Browsing an excessive number of similar websites or reading excessively similar product information from multiple sources may engender similarity confusion; introducing newly updated online payment technologies or assorted product combinations at varying prices can trigger ambiguity confusion; and providing a vast amount of information may cause overload confusion (Walsh et al., 2007).

Consumer confusion has long been considered an important topic in the consumer behaviour literature (Mitchell et al., 2005; Walsh \& Mitchell, 2010; Walsh et al., 2007). Understanding consumer confusion can help businesses improve their marketing strategies and establish sustainable and profitable relationships with their target consumers (Turnbull et al., 2000). Most papers on consumer confusion have investigated its antecedents and consequences (Cheng, Lu, \& Gursoy, 2015; Tjiptono, Arli, \& Bucic, 2014; Walsh \& Mitchell, 2010; Walsh et al., 2007; Wobker, Eberhardt, \& Kenning, 2015). Among those consequences, marketplace trust has been verified to be significantly decreased by consumer's confusion (Cheng et al., 2015; Walsh \& Mitchell, 2010; Walsh et al., 2007).

However, only a few papers have discussed the moderating effects of consumer confusion. In the complex online shopping environment, this study examines whether consumer confusion can alter the strength or direction of the relationships between distinct involvement types and specific trust objects (Baron \& Kenny, 1986). Product-involved consumers who adopt a long-term uncertainty-reduction strategy are less susceptible to the influence of a confusing context. Conversely, purchaseinvolved consumers often spend time and effort in seeking or processing information to evaluate their alternatives during the purchase process (Sanchez-Franco, 2009); this type of situational involvement is easily influenced by product attributes (e.g., product complexity and similarity) and situational variables (e.g., asymmetry in the availability of information related to decision-making) (Houston \& Rothschild, 1978). Therefore, a complex and unfamiliar shopping environment places the consumers' purchase decisions in a highly confusing situation. If these consumers feel confused when shopping online, then the effect of their purchase involvement on their trust may be reduced. On the basis of the above discussion, we formed the following hypotheses:

H3a: A consumer's confusion negatively moderates the relationship between his or her purchase involvement and trust in e-retailers. 
H3b: A consumer's confusion negatively moderates the relationship between his or her purchase involvement and trust in brands being sold online.

H3c: A consumer's confusion negatively moderates the relationship between his or her purchase involvement and trust in e-service providers.

\section{Methodology Questionnaire development}

This study developed a two-section questionnaire based on the literature review. The first section consists of three constructs and eight dimensions: consumer confusion (i.e., similarity, overload and ambiguity), product involvement (i.e., product and purchase) and trust (i.e., in e-vendor, retail website and brand). The consumer confusion scale was adapted from Walsh et al. (2007), while product involvement and purchase involvement were measured by using scales from Sanchez-Franco (2009) and Lockshin et al. (1997). The respondents' trust was measured by using three dimensions, namely, trust in e-vendors, trust in retail websites and trust in brands, with scales adapted from Bhattacherjee (2002), Gefen (2000), Delgado-Ballester and Munuera-Alemán (2001) and Jarvenpaa, Tractinsky and Vitale (2000) (see Table 1-A1, Appendix 1 for details). The second section gathers the demographic information of the respondents, including their gender, age, education, marital status, years of online shopping and monthly personal income. All items in the constructs were measured by using a seven-point Likert-type scale.

The English measurement items were translated into Chinese and then translated back into English by a bilingual expert to ensure translation accuracy. The survey instrument was then pilot-tested among 35 randomly selected college students to ensure its validity and reliability. In China, most college students are active Internet shoppers (Huang, Zhou, Liao, Mo, \& Wang, 2017), which justifies the pilot-test sampling. Based on the results of reliability analysis and item analysis, some measure items were deleted from the original scales to reach better scale consistency.

\section{Sampling and data collection}

Since the population this study focused on the Internet shoppers, we applied the online survey as our sampling method. The online survey, which was run by a professional opinion pollster, randomly selected participants from online users in Guangdong Province for 3 months. According to the Alibaba Group (China Business Intelligence Network, 2018), e-retailing sales in Guangdong Province accounted for 25\% of national sales and exceeded those in other parts of China in 2017, thereby enhancing the representativeness of the collected data. Those respondents who had never shopped online were excluded from the interviews. A total of 598 participants completed the questionnaire, among which 28 were excluded because they were inconsistent or had too many missing data, thereby leaving 570 effective samples for the analysis. The sample included 263 men (46.1\%) and
307 women (53.9\%). Respondents aged below 33 years and with a bachelor's degree or above accounted for $82.4 \%$ and $67.5 \%$ of the sample respectively. Almost all respondents $(92.8 \%)$ had more than 2 years of online shopping experience, and most of them $(64.9 \%)$ were earning below $5000 \mathrm{RMB}$ every month.

\section{Ethical consideration}

This article followed all ethical standards for carrying out research without direct contact with human or animal subjects.

\section{Results}

Structural equation modelling (SEM) was performed to analyse the collected data because of its ability to measure and test the causal relationships among latent variables. The second-order structure of consumer confusion must be analysed before estimating the entire proposed model because of its multi-dimensional character. Confirmatory factor analysis (CFA) was initially performed to test the convergent and discriminant validities of the second-order model of consumer confusion and the overall model before evaluating their fitness. Afterward, the proposed hypotheses were tested in the conceptual model.

\section{Confirmatory factor analysis}

Maximum likelihood estimation was conducted to estimate the confirmatory and structural equation models. The multidimensional factor of consumer confusion was tested before evaluating the fitness of the entire structural model. Confirmatory factor analysis was performed first to test the model fit of three second-order components (i.e., similarity, overload and ambiguity confusion) and one first-order construct (i.e., consumer confusion). As shown in Tables 1 and 2, all factor loadings (i.e., standardised coefficients) are above 0.6. The Cronbach's $\alpha$ and CR of the second-order components all exceed 0.7, while their average variance extracted (AVE) meet the suggested level of 0.5, thereby confirming the convergent validity and internal consistency of the measurement scales (Fornell \& Larcker, 1981; Hair, Black, Babin, \& Anderson, 2010). Discriminant validity was also achieved because the inter-factor correlations in the corresponding rows and columns were less than the square roots of AVE on the main diagonal (Fornell \& Larcker, 1981). The fit indices showed a favourable overall fit for the secondorder model (Hair et al., 2010). Consequently, the items concerning the three types of consumer confusion were averaged dimensionally to obtain three indicators of the main construct.

The proposed model was tested after performing secondorder CFA on consumer confusion. An item-parcelling strategy was applied across the entire model to obtain highly reliable indicators, to estimate fewer parameters and to simplify the model interpretation (Hau \& Marsh, 2004). Confirmatory factor analysis was also conducted to examine 
TABLE 1: Second-order confirmatory factor analysis, reliability and model fit ( $n=527)$.

\begin{tabular}{|c|c|c|c|c|c|c|c|c|c|c|c|c|c|}
\hline Construct & Dimensions & Items & Factor loadings & Cronbach's $\alpha$ & CR & $\chi^{2}(24)$ & $p$ & $\chi^{2} / \mathrm{df}$ & NFI & CFI & GFI & TLI & RMSEA \\
\hline \multirow{9}{*}{ Consumer confusion (CC) } & Similarity confusion (SC) & SC1 & 0.81 & 0.763 & 0.769 & - & - & - & - & - & - & - & - \\
\hline & & $\mathrm{SC} 2$ & 0.71 & - & - & - & - & - & - & - & - & - & - \\
\hline & & SC3 & 0.65 & - & - & - & - & - & - & - & - & - & - \\
\hline & Overload confusion (OC) & OC1 & 0.80 & 0.825 & 0.829 & - & - & - & - & - & - & - & - \\
\hline & & $\mathrm{OC2}$ & 0.88 & - & - & - & - & - & - & - & - & - & - \\
\hline & & OC3 & 0.67 & - & - & - & - & - & - & - & - & - & - \\
\hline & Ambiguity confusion (AC) & $\mathrm{AC1}$ & 0.81 & 0.822 & 0.824 & - & - & - & - & - & - & - & - \\
\hline & & $\mathrm{AC2}$ & 0.81 & - & - & - & - & - & - & - & - & - & - \\
\hline & & $\mathrm{AC} 3$ & 0.72 & - & - & - & - & - & - & - & - & - & - \\
\hline Goodness of fit indices & - & - & - & - & - & 52.988 & 0.000 & 2.208 & 0.973 & 0.985 & 0.979 & 0.977 & 0.048 \\
\hline
\end{tabular}

Note: Kaiser-Meyer-Olkin (KMO) test $=0.839$; Bartlett's test of sphericity $=1913.627, p=0.000$; varimax with Kaiser normalisation, 3 factors extracted; standardised 9 -item alpha $=0.721 ; \alpha>0.7$ reliable, $\alpha>0.8$ very reliable, $\alpha>0.9$ extremely reliable.

$\mathrm{CR}$, composite reliability; SC, similarity confusion; OC, overload confusion; AC, ambiguity confusion; NFI, normed fit index; CFI, comparative fit index; GFI, goodness of fit index; TLI, Tucker-Lewis index; RMSEA, root mean square error of approximation.

TABLE 2: Second-order factor means, standard deviations, Pearson correlations and validities $(n=527)$.

\begin{tabular}{|c|c|c|c|c|c|c|c|}
\hline Construct & Dimensions & Mean & SD & AVE & SC & OC & AC \\
\hline \multirow[t]{3}{*}{ Consumer confusion (CC) } & Similarity confusion (SC) & 4.941 & 1.229 & 0.528 & 0.727 & - & - \\
\hline & Overload confusion (OC) & 4.591 & 1.349 & 0.621 & $0.569 * *$ & 0.788 & - \\
\hline & Ambiguity confusion (AC) & 5.037 & 1.153 & 0.610 & $0.527 * *$ & $0.569 * *$ & 0.781 \\
\hline
\end{tabular}

Note: The square roots of AVE are located along the diagonal and the inter-construct correlations are shown in the lower left off-diagonal elements in the matrix.

$\mathrm{SD}$, standard deviations; AVE, average variance extracted; SC, similarity confusion; OC, overload confusion; AC, ambiguity confusion.

$*, p<0.05, * *, p<0.01$.

TABLE 3: First-order confirmatory factor analysis, reliability and model fit $(n=527)$.

\begin{tabular}{|c|c|c|c|c|c|c|c|c|c|c|c|c|}
\hline Constructs & Items & Factor loadings & Cronbach's $\alpha$ & CR & $\chi^{2}(307)$ & $p$ & $\chi^{2} / d f$ & $\mathrm{NFI}$ & CFI & GFI & TLI & RMSEA \\
\hline \multirow[t]{3}{*}{ Consumer confusion (CC) } & SC & 0.73 & 0.716 & 0.791 & - & - & - & - & - & - & - & - \\
\hline & $\mathrm{OC}$ & 0.78 & - & - & - & - & - & - & - & - & - & - \\
\hline & $A C$ & 0.78 & - & - & - & - & - & - & - & - & - & - \\
\hline \multirow[t]{3}{*}{ Product involvement (PD) } & PD1 & 0.70 & 0.846 & 0.850 & - & - & - & - & - & - & - & - \\
\hline & PD2 & 0.88 & - & - & - & - & - & - & - & - & - & - \\
\hline & PD3 & 0.84 & - & - & - & - & - & - & - & - & - & - \\
\hline \multirow[t]{4}{*}{ Purchase involvement (PC) } & PC1 & 0.80 & 0.831 & 0.863 & - & - & - & - & - & - & - & - \\
\hline & PC2 & 0.89 & - & - & - & - & - & - & - & - & - & - \\
\hline & PC3 & 0.76 & - & - & - & - & - & - & - & - & - & - \\
\hline & PC4 & 0.57 & - & - & - & - & - & - & - & - & - & - \\
\hline \multirow[t]{3}{*}{ Trust in e-vendor (TV) } & TV1 & 0.72 & 0.832 & 0.834 & - & - & - & - & - & - & - & - \\
\hline & TV2 & 0.77 & - & - & - & - & - & - & - & - & - & - \\
\hline & TV3 & 0.88 & - & - & - & - & - & - & - & - & - & - \\
\hline \multirow[t]{3}{*}{ Trust in retail website (TW) } & TW1 & 0.83 & 0.845 & 0.846 & - & - & - & - & - & - & - & - \\
\hline & TW3 & 0.74 & - & - & - & - & - & - & - & - & - & - \\
\hline & TW4 & 0.73 & - & - & - & - & - & - & - & - & - & - \\
\hline \multirow[t]{4}{*}{ Trust in brand (TB) } & TB1 & 0.72 & 0.811 & 0.815 & - & - & - & - & - & - & - & - \\
\hline & TB2 & 0.79 & - & - & - & - & - & - & - & - & - & - \\
\hline & TB3 & 0.77 & - & - & - & - & - & - & - & - & - & - \\
\hline & TB4 & 0.61 & - & - & - & - & - & - & - & - & - & - \\
\hline Goodness of fit indices & - & - & - & - & 572.296 & 0.000 & 1.864 & 0.905 & 0.953 & 0.923 & 0.947 & 0.041 \\
\hline
\end{tabular}

$\mathrm{CR}$, composite reliability; AVE, average variance extracted; SC, similarity confusion; OC, overload confusion; AC, ambiguity confusion; $\mathrm{NFI}$, normed fit index; $\mathrm{CFI}$, comparative fit index; GFI, goodness of fit index; TLI, Tucker-Lewis index; RMSEA, root mean square error of approximation.

Note: Kaiser-Meyer-Olkin (KMO) test $=0.893$; Bartlett's test of sphericity $=4408.95, p=0.000$; varimax with Kaiser normalisation, 6 factors extracted; standardised 23 -item alpha $=0.885 ; \alpha>0.7$ reliable, $\alpha>0.8$ very reliable, $\alpha>0.9$ extremely reliable;

whether the collected data fit the hypothesised measurement model (i.e., consumer confusion, product involvement, purchase involvement, trust in e-vendor, trust in retail website and trust in brand). As shown in Tables 3 and 4, a favourable model fit is achieved because the $\chi^{2} /$ d.f. ratio is less than 3 , the values of NFI, GFI, CFI and TLI are all above 0.90 and the RMSEA is below 0.08 (Hair et al., 2010). The convergent validity and internal consistency of the measurement scales were also confirmed because almost all values for the factor loadings, Cronbach's $\alpha$, and CR exceeded 0.7 while their AVEs met the suggested level of 0.5. Similarly, the test for discriminant validity presented a satisfactory outcome because the square root AVE estimates of a single construct were greater than the inter-construct correlations.

\section{Simultaneous regression paths}

SEM regression paths were constructed to test the proposed hypotheses in the conceptual model as shown in Figure 1. Purchase involvement is negatively related to trust in 
TABLE 4: First-order factor means, standard deviations, Pearson correlations and validities $(n=527)$.

\begin{tabular}{|c|c|c|c|c|c|c|c|c|c|}
\hline Constructs & Mean & SD & AVE & CC & PD & PC & TV & TW & TB \\
\hline Consumer confusion (CC) & 4.848 & 0.995 & 0.558 & 0.747 & - & - & - & - & - \\
\hline Product involvement (PD) & 5.550 & 1.041 & 0.657 & $0.402 * *$ & 0.811 & - & - & - & - \\
\hline Purchase involvement (PC) & 5.162 & 1.096 & 0.584 & $0.353^{* *}$ & $0.459 * *$ & 0.764 & - & - & - \\
\hline Trust in e-vendor (TV) & 4.420 & 0.999 & 0.629 & $-0.148 * *$ & $0.437 * *$ & $-0.418 * *$ & 0.793 & - & - \\
\hline Trust in retail website (TW) & 4.800 & 1.073 & 0.579 & $-0.258 * *$ & $0.269 * *$ & $-0.269 * *$ & $0.537 * *$ & 0.761 & - \\
\hline Trust in brand (TB) & 4.734 & 0.955 & 0.527 & $-0.207 * *$ & $0.352 * *$ & $-0.300 * *$ & $0.526 * *$ & $0.519 * *$ & 0.726 \\
\hline
\end{tabular}

Note: The square roots of AVE are located along the diagonal and the inter-construct correlations are shown in the lower left off-diagonal elements in the matrix.

CC, consumer confusion; PD, product involvement; PC, purchase involvement; TV, trust in e-vendor; TW, trust in retail website; TB, trust in brand; SD, standard deviations; AVE, average variance extracted.

$*, p<0.05, * *, p<0.01$.

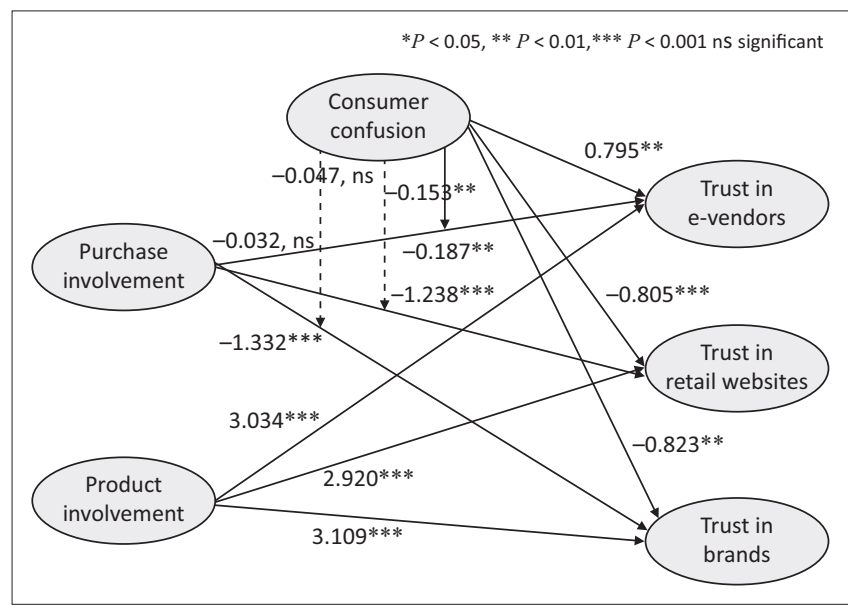

ns, not significant.

$*, p<0.05 ; * *, p<0.01 ; * * *, p<0.001$

FIGURE 1: Estimation results of structural model.

e-vendors $(\beta=-1.187, p<0.001)$, retail websites $(\beta=-1.238$, $p<0.001)$ and brands $(\beta=-1.332, p<0.001)$, thereby not supporting H1a, H1b and H1c. Meanwhile, consumers with a high purchase involvement exhibit low trust in e-commerce. Hypothesis 2, which predicts a positive relationship between product involvement and trust in e-business, was also verified by the results concerning the e-vendors $(\beta=3.034$, $p<0.001)$, trust in retail websites $(\beta=2.920, p<0.05)$ and trust in brands $(\beta=3.109, p<0.001)$. Therefore, H2a, H2b and H2c are all supported. In other words, as the consumers' product involvement increases, they tend to trust retailers, retail websites and brands while shopping online.

A quadratic latent variable with a single indicant was applied to test the moderating effect of consumer confusion. Although all possible pairwise products of the main effect were recommended as indicators of the latent product to examine the interaction (Kenny \& Judd, 1984), unfortunately, the product terms violate the multivariate normality of the maximum likelihood assumption (Cortina, Chen, \& Dunlap, 2001; Ping, 1995). Given this problem, many authors have proposed a single indicator of the latent product (Jöreskog \& Yang, 1996; Mathieu, Tannenbaum, \& Salas, 1992; Ping, 1995). The moderating effects of consumer confusion was tested by using a single indicant specification, and the results are also shown in Figure 1. Consumer confusion demonstrates a significant and negative moderating effect on the negative relationship between purchase involvement and trust in

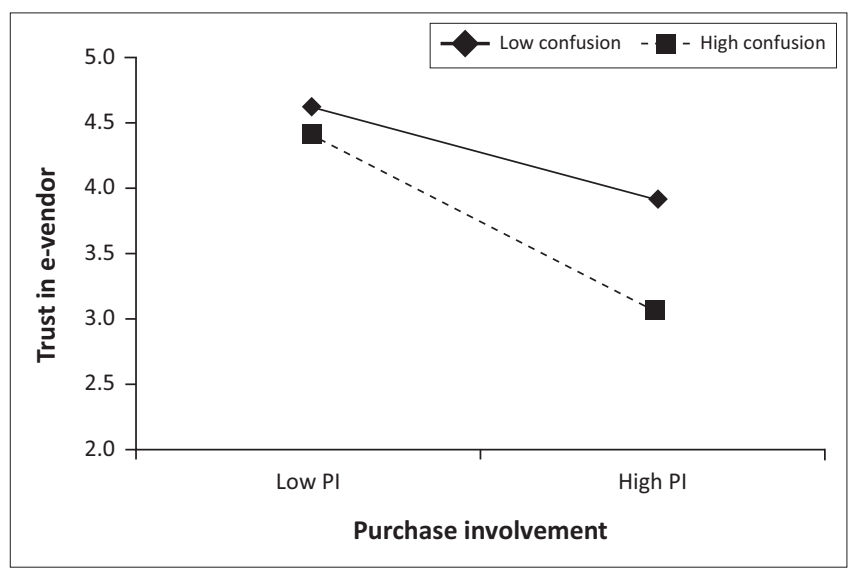

FIGURE 2: Interaction of purchase involvement and confusion on trust in e-vendors.

e-vendors $(\beta=-0.153, p<0.01)$. By contrast, the moderating effects of consumer confusion on the relationships between purchase involvement and trust in retail websites ( $\beta=-0.047, \mathrm{~ns})$ and trust in brands $(\beta=-0.032, \mathrm{~ns})$ fail to reach a significant level. Therefore, $\mathrm{H} 3 \mathrm{a}$ is supported, while $\mathrm{H} 3 \mathrm{~b}$ and $\mathrm{H} 3 \mathrm{c}$ are rejected. The interacting effect of purchase involvement and confusion on trust in e-vendors is illustrated in Figure 2. The plot of interaction shows that trust in e-vendors decreases along with purchase involvement; however, this slope descends more sharply for higher confusion. This finding indicates that high purchaseinvolved and confused consumers tend to have lower trust in e-vendors.

\section{Discussion}

Shoppers struggle when making decisions in the confusing, low-trust e-commerce environment. This study investigated the involvement-trust relationship and the moderating effect of consumer confusion. The results show that purchase involvement has a negative impact on online trust in e-vendors, retail websites and brands, whereas product involvement demonstrates a positive impact. In a confusing shopping environment, involvement is not always positively related to trust, which demonstrates a new relationship between involvement and trust. This finding supplements the theory proposed in Chen et al. (2016) and Sanchez-Franco (2009) in a low-trust context. This study also confirms that consumer confusion negatively moderates the relationship between purchase involvement and trust in e-vendors. 
Given their poor knowledge in online shopping, purchaseinvolved consumers have low trust in e-vendors, retail websites and brands. Purchase involvement is situational and can be easily affected by one's surroundings (Houston \& Rothschild, 1978). Consumers with a high purchase involvement are greatly affected by the negative image of online shopping and readily show low levels of trust belief toward e-commerce. In the worst-case scenario, these consumers may no longer trust online shopping and refrain from engaging in e-commerce transactions, thereby leading to a trade reduction. By contrast, product-involved consumers constantly focus on certain products or services before starting the purchase process. They exhibit great familiarity from enthusiasm and excitement, are capable of distinguishing good products and services from bad ones and can adopt effective strategies to reduce their perceived risks. Therefore, consumers with a high product involvement can easily identify trustworthy e-vendors, brands and retail websites with which they can transact online. Meanwhile, consumer confusion has a significant and negative moderating effect on the negative relationship between purchase involvement and trust in e-vendors. Given that consumer confusion is negatively related to trust in e-vendors (see Figure $1 ; \beta=-0.795, p<0.01$ ), consumer confusion reinforces the negative relationship.

In the face of these situational involvements, consumers take certain precautions against risks, such as by seeking additional information. When searching for information before conducting transactions, purchase-involved shoppers must browse numerous unfamiliar choices. Online retailers greatly outnumber the e-merchant marketplaces or brands that operate online. For instance, two top-ranked US e-commerce platforms, namely Amazon and eBay, held over half of e-commerce sales in 2017, while Tmall.com and JD.com, the two most well-known business-to-consumer (B2C) retail markets in China, already dominated more than three-quarters of the entire online market share (China Internet Watch, 2016). Conversely, the number of online retailers has increased dramatically. In 2017, the number of e-commerce companies in the US amounted to 300000 (Murthy, 2017) and, surprisingly, the number of customer-tocustomer (C2C) stores in China had reached 12 million (E-commerce statistics, 2017). These small stores grow faster than large ones because of their minimal start-up costs, yet enjoy a lower reputational advantage (Gao, Chan, Chi, \& Deng, 2016). Therefore, in such a complex information environment created by e-retailers, purchase-involved consumers struggle when making purchase decisions because of their insufficient product and service knowledge and the lack of trustworthy stores. As a result, consumer confusion can eventually lead to a low trust in e-vendors. By contrast, given the small number of e-service providers and brands being sold online, consumers are less likely to become confused in platform and brand shopping, thereby explaining the insignificant moderating effects of consumer confusion on the relationships between purchase involvement and trust in the other two objects (i.e., retail websites and brands).

\section{Managerial implications}

For practitioners, the findings provide important implications that consumer trust is an essential factor in e-commerce transactions. To enhance consumer trust in online settings, marketers must learn how to decrease uncertainty and confusion in the purchase process. Moreover, the involvement in establishing a trust-based relationship between consumers and suppliers must be emphasised. Some recommendations for practitioners are as follows: (1) To enhance the trust beliefs of purchase-involved consumers, marketers should invite regular customers (product-involved customers) to recommend their products and services during online transactions. Current customers, serving as a trusted third party, can be rewarded by allowing them to invite their ingroup members to be involved in transactions. (2) To lessen the moderating effect of confusion, online retailers should set up shops on well-known e-commerce platforms or sell famous brands. Through being associated with e-service providers and brands, e-merchants can increase purchaseinvolved consumers' trust beliefs toward e-retailers. (3) Finally, to reduce consumer confusion, e-retailers should differentiate themselves from others in the same merchandise category. Distinct logos, slogans and advertising styles can easily be identified by purchase-involved consumers.

\section{Conclusion}

Few studies have recognised the effects of involvement on trust in the full-scale context of online shopping. The moderating effect of confusion has also received little academic attention. Chinese shoppers struggle in the confusing, low-trust environment of the largest retail e-commerce market. This study, therefore, explored the relationships between consumer involvement and trust in the e-commerce setting. Moreover, the moderating effect of confusion was also assessed regarding these associations. The results show that purchase involvement has a negative impact on online trust in e-vendors, retail websites and brands, whereas product involvement has a positive impact. This study also confirms that confusion moderates the relationship between purchase involvement and trust in e-vendors.

\section{Limitations and further research}

Several limitations exist in the present study. First, we applied an item-parcelling strategy to present a concise model. However, the second-order components (i.e., similarity, overload and ambiguity confusion) may exert distinct moderating effects on the involvement-trust relationship. Future research could be aimed at how different types of confusion may decrease the influence of involvement on trust. Second, though China is the largest e-commerce market globally (Lipsman, 2019), Chinese e-shopping setting may, to some extent, limit the generalisation of our findings to the rest of the world. In contrast with Sanchez-Franco's (2009) findings from the investigation in Spain, our research reveals a negative relationship between involvement and 
trust. We would like to attribute this different result to the contextual factors rather than country ones. Hence, future studies can explore the involvement-trust relationship in some other settings to extend theories.

\section{Acknowledgements}

Raya Merenkov is appreciated for her editorial assistance. This research is supported by the Institute of Guangdong \& Taiwan (KFJJ201802), Philosophy and Social Science Planning Project of Guangdong Province (GD18CGL05) and Guangdong Science and Technology Project (180917114960500).

\section{Competing interests}

The authors have declared that no competing interest exists.

\section{Authors' contributions}

All authors contributed equally to this work.

\section{Funding information}

This research is supported by the Institute of Guangdong \& Taiwan (KFJJ201802), Philosophy and Social Science Planning Project of Guangdong Province (GD18CGL05) and Guangdong Science and Technology Project (180917114960500).

\section{Data availability statement}

Data sharing is not applicable to this article as no new data were created or analysed in this study.

\section{Disclaimer}

The views and opinions expressed in this article are those of the authors and do not necessarily reflect the official policy or position of any affiliated agency of the authors.

\section{References}

Andrews, J.C., Durvasula, S., \& Akhter, S.H. (1990). A framework for conceptualizing and measuring the involvement construct in advertising research. Journal of Advertising, 19(4), 27-40. https://doi.org/10.1080/00913367.1990.10673198

Bao, Y.Y. (2013). Chinese sports brands see sales slump. Retrieved from http://en.ce. cn/Insight/201301/09/t20130109_24015212.shtml

Barki, H., \& Hartwick, J. (1994). Measuring user participation, user involvement, and user attitude. MIS Quarterly, 18(1), 59-82. https://doi.org/10.2307/249610

Baron, R.M., \& Kenny, D.A. (1986). The moderator-mediator variable distinction in social psychological research: Conceptual, strategic, and statistical considerations. Journal of Personality and Social Psychology, 51(6), 1173-1182. https://doi. org/10.1037/0022-3514.51.6.1173

Belanche, D., Flavián, C., \& Pérez-Rueda, A. (2017). Understanding interactive online advertising: Congruence and product involvement in highly and lowly arousing, skippable video ads. Journal of Interactive Marketing, 37, 75-88. https://doi. org/10.1016/j.intmar.2016.06.004

Bhattacherjee, A. (2002). Individual trust in online firms: Scale development and initia trust. Journal of Management Information Systems, 19(1), 213-243. https://doi. org/10.1080/07421222.2002.11045715

Bloch, P.H., \& Richins, M.L. (1983). A theoretical model for the study of product importance perceptions. Journal of Marketing, 47(3), 69-81. https://doi. org/10.1177/002224298304700308

Chen, Y.H., Wu, J.J., \& Chien, S.H. (2016). Impact of initial trust, involvement, and mood on trusting belief: Evidence from the financial industry in Taiwan. Journal of Service Theory and Practice, 26(1), 91-108. https://doi.org/10.1108/JSTP-11 2014-0252

Cheng, A., Lu, C., \& Gursoy, D. (2015). A conceptual model of consumers' online tourism confusion. International Journal of Contemporary Hospitality Management, 27(6), 1320-1342. https://doi.org/10.1108/IJCHM-04-2014-0171
China Business Intelligence Network. (2018). Alibaba: Report on China's Digital Economy Development in 2017. Retrieved from http://www.askci.com/news/ chanye/20180111/163808115843.shtml

China Internet Watch. (2016). Retails e-commerce sales share worldwide 2015-2020. Retrieved from https://www.chinainternetwatch.com/18977/

CIGI-Ipsos. (2018). 2018 CIGI-Ipsos global survey on internet security and trust Retrieved from https://www.cigionline.org/internet-survey-2018

Cortina, J.M., Chen, G., \& Dunlap, W.P. (2001). Testing interaction effects in LISREL: Examination and illustration of available procedures. Organizational Research Methods, 4(4), 324-360. https://doi.org/10.1177/109442810144002

Delgado-Ballester, E., \& Munuera-Alemán, J.L. (2001). Brand trust in the context of consumer loyalty. European Journal of Marketing, 35(11-12), 1238-1258. https:// doi.org/10.1108/EUM0000000006475

E-Commerce Statistics. (2017). E-commerce: these big data reveal the survival status of online stores. Retrieved from http://www.ebrun.com/20170630/236799.shtml

Ecommerce Foundation. (2017). Global Ecommerce Report 2017. Retrieved from https://mazarsusa.com/wp-content/uploads/2017/11/Global-Report-2017.pdf

Ferns, B.H., \& Walls, A. (2012). Enduring travel involvement, destination brand equity, and travelers' visit intentions: A structural model analysis. Journal of Destination Marketing and Management, 1(1-2), 27-35. https://doi.org/10.1016/j.jdmm. 2012.07.002

Fornell, C., \& Larcker, D.F. (1981). Evaluating structural equation models with unobservable variables and measurement error. Journal of Marketing Research 18(1), 39-50. https://doi.org/10.1177/002224378101800104

Gao, B., Chan, W.K.V., Chi, L., \& Deng, X.N. (2016). Size and growth dynamics of online stores: A case of China's Taobao.com. Electronic Commerce Research and Applications, 17, 161-172. https://doi.org/10.1016/j.elerap.2016.04.005

Gefen, D. (2000). E-commerce: The role of familiarity and trust. Omega-Internationa Journal of Management Science, 28(6), 725-737. https://doi.org/10.1016/S0305Journal of Manage
0483(00)00021-9

Grabner-Kräuter, S., \& Kaluscha, E.A. (2003). Empirical research in on-line trust: A review and critical assessment. International Journal of Human-Computer Studies, 58(6), 783-812. https://doi.org/10.1016/S1071-5819(03)00043-0

Hair, J.F., Black, W.C., Babin, B.J., \& Anderson, R.E. (2010). Multivariate data analysis: A global perspective. Upper Saddle River, NJ: Pearson.

Hansen, T. (2017). How trust in financial supplier information impacts young adults financial information involvement: The moderating roles of product savings risk and social norm. Journal of Consumer Behaviour, 16(3), 221-232. https://doi. org/10.1002/cb.1638

Hau, K.T., \& Marsh, H.W. (2004). The use of item parcels in structural equation modelling: Non-normal data and small sample sizes. British Journal of Mathematical and Statistical Psychology, 57(2), 327-351. https://doi.org/ 10.1111/j.2044-8317.2004.tb00142.x

Houston, M.J., \& Rothschild, M.L. (1978). Conceptual and methodological perspectives on involvement. In S. Jain (Eds), Research frontiers in marketing dialogues and directions (pp. 184-187). Chicago, IL: American Marketing Association.

Huang, J., Zhou, J., Liao, G., Mo, F., \& Wang, H. (2017). Investigation of Chinese students' $\mathrm{O} 2 \mathrm{O}$ shopping through multiple devices. Computers in Human Behavior 75, 58-69. https://doi.org/10.1016/j.chb.2017.04.050

iiMedia Report. (2018). China imports e-Commerce authentic research report. Retrieved from http://www.iimedia.cn/63004.html

Jarvenpaa, S., Tractinsky, N., \& Vitale, M. (2000). Consumer trust in an Internet store. Information Technology and Management, 1(1-2), 45-71. https://doi.org/ 10.1023/A:1019104520776

Jöreskog, K.G., \& Yang, F. (1996). Nonlinear structural equation models: The KennyJudd model with interaction effects. In G.A. Marcoulides \& R.E. Schumacker (eds.) Advanced structural equation modeling techniques (pp. 57-88). Hillsdale, NJ: Lawrence Erlbaum.

Kenny, D., \& Judd, C.M. (1984). Estimating the nonlinear and interactive effects of latent variables. Psychological Bulletin, 96(1), 201-210. https://doi.org/10.1037/ 0033-2909.96.1.201

Kim, J.K., Ferrin, D.L., \& Rao, H.R. (2008). A trust-based consumer decision-making model in electronic commerce: The role of trust, perceived risk, and their antecedents. Decision Support Systems, 44(2), 544-564. https://doi.org/10.1016/ j.dss.2007.07.001

Laurent, G., \& Kapferer, J. (1985). Measuring consumer involvement profile. Journal of Marketing Research, 22(1), 41-53. https://doi.org/10.1177/002224378502200104

Lee, M.K.O., \& Turban, E. (2001). A trust model for consumer Internet shopping. International Journal of Electronic Commerce, 6(1), 75-91. https://doi.org/10. 1080/10864415.2001.11044227

Li, Y., Li, G., \& Feng, T. (2015). Effects of suppliers' trust and commitment on customer involvement. Industrial Management and Data Systems, 115(6), 1041-1066. https://doi.org/10.1108/IMDS-11-2014-0351

Lipsman, A. (2019). Global ecommerce 2019: Ecommerce continues strong gains amid global economic uncertainty. Retrieved from https://www.emarketer.com/ content/global-ecommerce-2019

Lockshin, L.S., Spawton, A.L., \& Macintosh, G. (1997). Using product, brand and purchasing involvement for retail segmentation. Journal of Retailing and Consumer Services, 4(3), 171-183. https://doi.org/10.1016/S0969-6989(96) Consumer

Mathieu, J.E., Tannenbaum, S.I., \& Salas, E. (1992). Influences of individual and situational characteristics on measures of training effectiveness. Academy of Management Journal, 35(4), 828-847. https://doi.org/10.5465/256317 
McKnight, D.H., Choudhury, V., \& Kacmar, C. (2002). Developing and validating trust measures for e-commerce: An integrative typology. Information Systems trust measures for e-commerce: An integrative typology. Informm
Research, 13(3), 334-359. https://doi.org/10.1287/isre.13.3.334.81

Mitchell, V.W., Walsh, G., \& Yami, M. (2005). Towards a conceptual model of consumer confusion. Advances in Consumer Research, 32(1), 143-150.

Moon, S.J., Costello, J.P., \& Koo, D.M. (2016). The impact of consumer confusion from eco-labels on negative WOM, distrust, and dissatisfaction. International Journal of Advertising, 36(2), 246-271. https://doi.org/10.1080/02650487.2016.1158223

Murthy, A. (2017). How many e-commerce companies are there? What's the global e-commerce market size? Retrieved from http://blog.pipecandy.com/e-commercee-commerce market size?
companies-market-size/

Ouyang, Z., Gursoy, D., \& Chen, K.-C. (2019). It's all about life: Exploring the role of residents' quality of life perceptions on attitudes toward a recurring hallmark
event over time. Tourism Management, 75, 99-111. https://doi:10.1016/j. tourman.2019.04.032

Pieniak, Z., Verbeke, W., Scholderer, J., Brunsø, K., \& Olsen, S.O. (2008). Impact of consumers' health beliefs, health involvement and risk perception on fish consumption. British Food Journal, 110(9), 898-915. https://doi.org/10.1108/ 00070700810900602

Ping, R.A. (1995). A parsimonious estimating technique for interaction and quadratic latent variables. Journal of Marketing Research, 32(3), 336-347. https://doi.org/ 10.1177/002224379503200308

Plassmann, H., Kenning, P., Deppe, M., Kugel, H., \& Schwindt, W. (2008). How choice ambiguity modulates activity in brain areas representing brand preference: Evidence from consumer neuroscience. Journal of Consumer Behaviour, 7(4-5) 360-367. https://doi.org/10.1002/cb.257

Rahman, I., \& Reynolds, D. (2015). Wine: Intrinsic attributes and consumers' drinking frequency, experience, and involvement. International Journal of Hospitality Management, 44, 1-11. https://doi.org/10.1016/j.ijhm.2014.09.004

Riquelme, I.P., Román, S., Cuestas, P.J., \& lacobucci, D. (2019). The dark side of good reputation and loyalty in online retailing: When trust leads to retaliation as consequence of dynamic pricing. Journal of Interactive Marketing, 47, 35-52. https://doi.org/10.1016/j.intmar.2018.12.002

Sanchez-Franco, M.J. (2009). The moderating effects of involvement on the relationships between satisfaction, trust and commitment in e-banking. Journal of Interactive Marketing, 23(3), 247-258. https://doi.org/10.1016/j.intmar.2009.04.007
Shiu, J.Y., \& Tzeng, S.Y. (2018). Consumer confusion moderates the inertia-purchase intention relationship. Social Behaviour and Personality, 46(3), 387-394. https:// doi.org/10.2224/sbp.6792

Singh, J., \& Sirdeshmukh, D. (2000). Agency and trust mechanisms in consume satisfaction and loyalty judgments. Journal of the Academy of Marketing Science, 28(1), 150-167. https://doi.org/10.1177/0092070300281014

Tjiptono, F., Arli, D., \& Bucic, T. (2014). Consumer confusion proneness: Insights from a developing economy. Marketing Intelligence and Planning, 32(6), 722-734. https://doi.org/10.1108/MIP-05-2013-0082

Turnbull, P.W., Leek, S., \& Ying, G. (2000). Customer confusion: The mobile phone market. Journal of Marketing Management, 16(1-3), 143-163. https://doi.org/ $10.1362 / 026725700785100523$

Vanwesenbeeck, I., Walrave, M., \& Ponnet, K. (2016). Children and advergames: The role of product involvement, prior brand attitude, persuasion knowledge and game attitude in purchase intentions and changing attitudes. International Journal of Advertising, 36(4), 520-541. https://doi.org/10.1080/02650487.2016. 1176637

Vogelstein, F. (2018). Why should anyone believe Facebook anymore? (Wired business). Retrieved from https://www.wired.com/story/facebook-data-sharingprivacy-investigation/

Walsh, G., \& Mitchell, V.M. (2010). The effect of consumer confusion proneness on word of mouth, trust, and customer satisfaction. European Journal of Marketing, 44(6), 838-859. https://doi.org/10.1108/03090561011032739

Walsh, G., Hennig-Thurau, T., \& Mitchell, V.M. (2007). Consumer confusion proneness: Scale development, validation, and application. Journal of Marketing Management, 23(7-8), 697-721. https://doi.org/10.1362/026725707X230009

Wobker, I., Eberhardt, T., \& Kenning, P. (2015). Consumer confusion in German food retailing: The moderating role of trust. International Journal of Retail and Distribution Management, 43(8), 752-774. https://doi.org/10.1108/IJRDM-072012-0061

Yang, S.C., Hung, W.C., Kai, S., \& Farn, C.K. (2006). Investigating initial trust toward e-retailers from the elaboration likelihood model perspective. Psychology and Marketing, 23(5), 429-445. https://doi.org/10.1002/mar.20120 


\section{Appendix 1}

TABLE 1-A1: Questionnaire items.

\begin{tabular}{|c|c|c|}
\hline Constructs & Items & Descriptions \\
\hline \multirow[t]{3}{*}{ Similarity confusion (SC) } & SC1 & Due to the great similarity of many products it is often difficult to detect new products. \\
\hline & SC2 & Some brands look so similar that it is uncertain whether they are made by the same manufacturer. \\
\hline & $\mathrm{SC} 3$ & Sometimes I want to buy a product seen in an advertisement but cannot identify it clearly between scores of similar products. \\
\hline \multirow[t]{3}{*}{ Overload confusion (OC) } & OC1 & I do not always know exactly which products meet my needs best. \\
\hline & $\mathrm{OC2}$ & There are so many brands to choose from that I sometimes feel confused. \\
\hline & Oc3 & Most brands are very similar and are therefore hard to distinguish. \\
\hline \multirow[t]{3}{*}{ Ambiguity confusion (AC) } & $\mathrm{AC1}$ & Products often have so many features that a comparison of different brands is barely possible. \\
\hline & $\mathrm{AC2}$ & The information I get from advertising often are so vague that it is hard to know what a product can actually perform. \\
\hline & $\mathrm{AC3}$ & When purchasing certain products, I need the help of sales personnel to understand differences between products. \\
\hline \multirow[t]{4}{*}{ Product involvement (PD) } & PD1 & I like to use the products I buy personally in my life. \\
\hline & PD2 & I often use the products I buy. \\
\hline & PD3 & The product I use says a lot about who I am. \\
\hline & PD4 & It is important for me to choose a product that 'feels' right. \\
\hline \multirow[t]{3}{*}{ Purchase involvement (PC) } & PC1 & In order to buy more cost-effective goods, I would like to spend extra time to do comparison shopping. \\
\hline & PC3 & Because of my personal values, I feel smart shopping ought to be important to me. \\
\hline & PC4 & I usually spend a lot of time and effort making an expensive purchase decision. \\
\hline \multirow[t]{4}{*}{ Trust in e-vendor (TV) } & TV1 & Based on my online shopping experience, the store is trustworthy. \\
\hline & TV2 & I trust that the store keeps my best interests, such as providing needed information, in mind. \\
\hline & TV3 & The store wants to be known as one who keeps promises and commitments. \\
\hline & TV4 & The company will always be honest with me. \\
\hline \multirow[t]{4}{*}{ Trust in retail website (TW) } & TW1 & Even if not monitored, I'd trust the retail website to do the job right. \\
\hline & TW2 & I trust the retail website I often visit. \\
\hline & TW3 & I am quite certain what to expect from the retail website. \\
\hline & TW4 & $\begin{array}{l}\text { It performs the work according to the entries on the registration protocol, such as the legitimate use of personal information } \\
\text { in accordance with the privacy policy. }\end{array}$ \\
\hline \multirow[t]{4}{*}{ Trust in brand (TB) } & TB1 & The brand offers me a product with a constant quality level. \\
\hline & TB2 & The brand helps me to solve any problem I could have with the product. \\
\hline & TB3 & The brand is interested in my satisfaction. \\
\hline & TB4 & The brand offers me recommendations and advice on how to make the most of this product. \\
\hline
\end{tabular}

SC, similarity confusion; OC, overload confusion; AC, ambiguity confusion; PD, product involvement; PC, purchase involvement; TV, trust in e-vendor; TW, trust in retail website; TB, trust in brand. 